\title{
Revealed Comparative Advantage and competitiveness: The caseof Palm oil Exportsfrom Nigeria, Ghana and Côte d'Ivoire.
}

\author{
Etuk, E.A*, Ohen, S.B \\ Department of Agricultural Economics, University of Calabar, Calabar, PMB, 1115; Postal code: 5400004 \\ Calabar, Ngeria. \\ Corresponding Author: Etuk, E.A
}

\begin{abstract}
This study analysed the export competitiveness of Palm oil in Nigeria, Ghana and Cote d'Ivoire. The specific objectives were to; determine the mean export quantity, and production quantity of palm oil in the selected countries; compute the Revealed Comparative Advantage (RCA) and the Revealed Symmetric Comparative Advantage (RSCA) indices for Nigeria, Ghana and Côte d'Ivoire with respect to palm oil exports. Data for the study was obtained from Food and Agricultural Organization (FAO) statistical database and analyzed using descriptive statistics and the Balassa index. The result of the study showed that the mean production and export quantity of palm oil for Nigeria, Ghana and Cote d'Ivoire were 964,161.3tonnes, 109,062.3tonnes, and 290,619.6 tonnes for palm oil production while palm oil export quantity was 7491.292 tonnes, 35,061.79 tonnes, and 135,838.3tonnes respectively. The empirical findings suggests that Côte d'Ivoire is highly competitive in the export of palm oil followed by Ghana and lastly Nigeria which is less competitive compared to the aforementioned countries. Policies and programmes to enhance Nigeria's palm oil output and make it more competitive is recommended.
\end{abstract}

Keywords: Palm oil, export, Revealed Comparative Advantage, Revealed Symmetric Comparative Advantage Balassa index

\section{Introduction}

International trade in Agricultural commodities contributes greatly to the economy of most SubSaharan African countries. For instance, $70 \%$ of all sub -Saharan Africa's global exports are commodity exports with 21 countries having $30 \%$ or more of their exports in commodities. These 21 countries represent $80 \%$ of sub-Sahara Africa's GDP and $60 \%$ of its population. More than $20 \%$ of sub-Saharan Africa's countries, are considered resource dependent as more than $20 \%$ of their fiscal revenues come from natural resources. Agriculture contributed 18\% of GDP in 2015 for Sub Saharan African countries, specifically, it contributed 21\% of Nigeria's GDP and constituted $4 \%$ of its total export value,and for Ghana $21 \%$, and $31.7 \%$; for Côte d'Ivoire 23\%and, 68.9\%; respectively (World Bank, 2017; World Trade Organization, 2017).From the foregoing, the apparent disparity in agriculture's contribution to the economies of these countries are obvious. While these may be attributable to various factors, export competitiveness plays a crucial role especially in agricultural trade.

Nigeria used to be the world's largest producer of palm oil before the crude oil boom era, currently Indonesia has taken the leading position followed by Malaysia with Nigeria, Ghana and Côte d'Ivoire placed fifth ninth and eleventh respectively (FAOSTAT, 2016). However, the crop and its derivative remains one of the most important economic domestic and export commodity in these countries. With the recent downturn in the economic fortunes of Nigeria, there has been a renewed call for diversification of the export basket of Nigeria away from well-established commodities such as cocoa and rubber to commodities that once contributed greatly to the foreign exchange earnings. However, while the contribution of these commodities to the country's export earnings declined, other countries, especially in South-East Asia became major exporters of these commodity. Making trade in palm oil a major income earner for Nigeria may depend on its comparative advantage considering the fact that Ghana and Côte d'Ivoire also export palm oil and have regions with similar agro ecological characteristics and also share a vision of strengthening their commodity exports development This study therefore, attempts to measure Nigeria's export competitiveness in the palm oil trade during the 19902013 period in comparison to Ghana and Côte d'Ivoire.

\section{Literature Review}

\subsection{Export Competitiveness and the theory of Revealed Comparative Advantage}

Conceptually, competitiveness is defined as the ability of a country (in this case) to offer products and services that meet local and international quality standards worth domestic and global market prices and provide adequate returns on the resources used in producing them. Competitiveness can be defined as the ability to face 
competition and to be successful when facing competition .Competitiveness is then the ability to sell products that meet demand requirements (price, quality, quantity) and, at the same time, ensure profits over time that enable the unit under study (Nation or firm) to thrive. Competition does occur either on the local markets (in the case of firms) or on the international market (if comparisons are made between countries). (Latruffe, 2010).

Trade theory suggests that a nation's competitiveness is based on the concept of comparative advantage. Trade flows among countries are the result of differences in their resource endowment and production costs. Under normal circumstances, a country will specialize in production of a good in which it has a cost advantage. Several measures of competitiveness suggested in trade theory have been applied in various works in Europe, Asia, the USA, and Africa. Among such measures are the real exchange rate and purchasing power parities (Brinkman, 1987), revealed comparative advantage and derived indicators (Vollrath, 1991), The net export index (NEI) (Banterle and Carraressi, 2007), Grubel-Lloyd measure (Banterle and Carraresi, 2007), the revealed comparative advantage (Valentine and Krasnick, 2000);(Oduro and Offei,2014), the revealed symmetric comparative advantage (Nwachuku,Agwu, Nwaru and Imonikhe,2010).

The concept of comparative advantage is widely used in modern economic literature to evaluate the patterns of trade and specialization of countries in commodities which have a competitive advantage (Saboniene, 2009). Revealed comparative advantage (Balassa, 1965) on the other hand, calculates the ratio of a country's export share of a commodity in the international market to the country's export share of all other commodities. For i-th country and $\mathrm{j}$-th commodity, RCA is defined as follows: $\mathrm{RCA}_{\mathrm{ij}}=\left(\mathrm{X}_{\mathrm{ij}} / \mathrm{X}_{\mathrm{ik}}\right) /\left(\mathrm{X}_{\mathrm{nj}} / \mathrm{X}_{\mathrm{nk}}\right)$ Where $\mathrm{X}$ are exports; $\mathrm{k}$ denotes all commodities other than $\mathrm{j}$; $n$ denotes all countries other than i. An increasing RCA index reflects increasing competitiveness. A RCA index greater than 1 indicates that the country " $\mathrm{i}$ " has a comparative advantage in the commodity under consideration, since it has a strong export sector. An RCA index greater than 1 reveals higher competitiveness (Latruffe, 2010). However, to address the problem of symmetry in $\mathrm{RCA}$, the index can be made asymmetric, as $(\mathrm{RCA}-1) /(\mathrm{RCA}+1)$; thus this measure ranges from -1 to +1 . This measure is referred to as the Revealed Symmetric Comparative Advantage (RSCA).RSCA better reflects the concept of specialization through its focus on a narrower area of economic within a given country, and less deep examination of other areas of activity (Laursen, 2015).

The concept of RCA and RSCA has been widely used in empirical studies of specialization and comparative advantage of countries. In investigating Ghana's revealed comparative advantage in AgroProcessed products, Oduro and Offei (2014) found that the revealed comparative advantage did not change radically over the period of study. However, a careful examination of the Balassa index showed that Ghana's RCA in agro-processed products somewhat weakened over time. Specifically, using four indices of revealed comparative advantage, they identified nine agro-processed product groups which Ghana has a comparative advantage. Ibrahim (2015), in examining the trade complementarity and similarity between Nigeria and India in the context of bilateral trade relations found that out of twenty major product categories, Nigeria has comparative advantage in only few products like mineral fuels, ships boats and floating structures, rubber and articles thereof, lac; gums resins and other vegetables. The RCA indices of these products were greater than one which implied that Nigeria can only export these products to India if and only if India has low comparative advantage in them. Based on the RCA indices Nigeria had comparative advantage in mineral fuels, rubber and articles thereof than India as it RCA indices of these products are 6.668 and 2.343 while that of India is 1.215 and 0.789 . Despite the comparative advantage with which the Nigeria has in ships boat and floating structures and lac; gums resins and other vegetable its scope of trade with India in these products will be limited because India also has comparative advantage in them more than Nigeria. Out of these twenty major products Nigeria can only export mineral fuels, rubber and articles of rubber to India. India has comparative advantage in most of the products than Nigeria. The RCA indices are greater than one in most of the products in case of India implying that it has more comparative advantage in most of the products than Nigeria Nwachukwu, Agwu, Nwaru,andImonikhe, (2010) using RCA and RSCA measure found that, Nigeria was highly competitive in the export of cocoa over the period under study. According to the authors, the level of competitiveness increased sharply between 1990 and 1995 which they attributed to positive response to export policy occasioned by the implementation of the Structural Adjustment Programme (SAP). However, the authors are not aware of any study that considered the export competitiveness and comparative advantage in palm oil trade between Nigeria, Ghana and Côte d'Ivoire

\subsection{Sources of Data}

\section{Data And Methodology}

The data used for this study were obtained from the Food and Agricultural Organization (FAO) statistical database. The study employed time series data on production, export of palm oil for Nigeria, Ghana, Côte d'Ivoire and the World. The values of exports were referred to in US dollars to net out the effect of changes in exchange rate. Data covered the period 1990 to 2013 during which consistent data was available for all countries. 
Revealed Comparative Advantage and competitiveness: The caseof Palm oil Exportsfrom Nigeria,

\subsection{Method of Data Analysis}

To overcome the difficulty of theoretically determining a country's comparative advantage using costs and prices before the economy is opened up to international trade, Balassa (1965) suggested that export results could be used to reveal the comparative advantage of a particular country in the absence of comprehensive data on factor costs. Specifically, the Export Performance Ratio (EPR) was determined using the Revealed Comparative Advantage (RCA) index also known as the Balassa index which is defined using export data only:

$$
R C A_{i}^{A}=\left(x_{i}^{A} / X^{A}\right),\left(x_{i}^{w} x_{i}^{w} / X^{w}\right)
$$

Where:

$$
\begin{aligned}
& x_{i}^{A}-\text { Country A exports of product I; } \\
& X^{A}-\text { Total exports of country A } \\
& x_{i}^{w}-\text { World exports of product } i \\
& X^{w}-\text { Total world exports }
\end{aligned}
$$

The index reveals a comparative advantage in export of commodity $i$ by country A if the index value is greater than one, and disadvantage if the index's value is less than one, with respect to the world or a set of reference countries. (Saboniene, 2009). The index so obtained will be made symmetric following Laursen (2015) thus: (RCA-1)/ $(\mathrm{RCA}+1)$

This measure ranges from- 1 to +1 and is referred to as Revealed Symmetric Comparative Advantage(RSCA).Positive (negative) values of RSCA show a competitive advantage(disadvantage) in exporting product $i$.Specifically, the index was operationalized thus;

$$
R C A_{i}^{A}=\left(x_{i}^{A} / X^{A}\right),\left(x_{i}^{w} / X^{w}\right)
$$

Where:

$$
\begin{aligned}
& x_{i}^{A}-\text { Value of Selected country's (Nigeria, Ghana, Côte d'Ivoire respectively) exports of palm oil; } \\
& X^{A}-\text { Total value of Agricultural exports of selected countries } \\
& x_{i}^{w}-\text { World exports of palm oil } \\
& X^{w}-\text { Total value of world agricultural exports }
\end{aligned}
$$

\section{Empirical Results}

4.1Mean production quantity and export quantity of palm oil in Nigeria, Ghana and Côte d'Ivoire (19902013). Table 1 shows the mean production quantity and export quantity of palm oil in Nigeria, Ghana and Côte d'Ivoire. It is observed that Nigeria's mean production quantity of palm oil $(964,161.3$ tonnes) is the highest, followed by Côte d'Ivoire with 290, 610.6 tonnes of palm oil while Ghana's mean production quantity of palm oil of 109,062.3 tonnes was the lowest during the period of study. From the same table, the export data shows that of the three countries, cote d'vior contributed the highest to total world export with a mean export quantity of 135,838.3 tonnes, followed by Ghana with a mean export quantity of 35,061.79 tonnes while Nigeria contributed the least to international trade in palm oil with a mean export quantity of 7,491.292 tonnes.

Table 1: Estimated mean production quantity and export quantity of palm oil in Nigeria, Ghana and Côte

$$
\text { d'Ivoire(1990-2013) }
$$

\begin{tabular}{llll}
\hline Variables & Nigeria & Ghana & Côte d'Ivoire \\
\hline Production quantity (PDQ) & $964,161.3$ & $109,062.3$ & $290,619.6$ \\
& $(180845.1)$ & $(13296.77)$ & $(53995.44)$ \\
Export quantity (EXQ) & 7491.292 & 35061.79 & $135,838.3$ \\
& $(7333.688)$ & $(28290.39)$ & $(59499.06)$ \\
\hline
\end{tabular}

Figures in parenthesis represent the standard deviation.

Source: Authors' computation, FAOSTAT, (2016) 
Revealed Comparative Advantage and competitiveness: The caseof Palm oil Exportsfrom Nigeria,

\subsection{Revealed Comparative Advantage (RCA) and Revealed Symmetric Comparative Advantage (RSCA) for palm oil export in Nigeria, Ghana and Côte d'Ivoire (1990-2013).}

The revealed comparative advantage for palm oil production in the three countries are presented in Table 2. The table shows that during 1990 to 1999, Nigeria had an RCA of less than 1 which means that Nigeria did not have a comparative advantage in the export of palm oil during this period. This is confirm by the negative value of RSCA. From 2000-2004, the RCA fluctuated from 1.22 during the 2000-2004 period to 1.23 and 1.10 during the 2005-2009 and 2010-2013 periods respectively, this period coincided with the re-birth of democratic governance in Nigeria that was favourably disposed to economic liberalization. The periods 2005 to 2013 recorded an RCA greater than unity which means that Nigeria had a comparative advantage in more recent years and hence, was competitive in the export of palm oil from 2000 to 2013.Comparatively, RCA index for Nigeria was lower than that of Ghana and Côte d'Ivoire implying that both countries have more comparative advantage in palm oil exports.

Table 2: Revealed Comparative Advantage (RCA) and Revealed Symmetric Comparative Advantage (RSCA) for palm oil export in Nigeria, Ghana and Côte d'Ivoire.

\begin{tabular}{llllll}
\hline \multicolumn{1}{c}{ Nigeria } & \multicolumn{5}{l}{} \\
\hline YEARS & $1990-1994$ & $1995-1999$ & $2000-2004$ & $2005-2009$ & $2010-2013$ \\
RCA & 0.002 & 0.996 & 1.22 & 1.23 & 1.10 \\
RSCA & -0.996 & -0.527 & 0.099 & 0.103 & 0.048 \\
\hline Ghana & & & & & $2010-2013$ \\
\hline YEARS & $1990-1994$ & $1995-1999$ & $2000-2004$ & $2005-2009$ & 1.906 \\
RCA & 0.372 & 1.006 & 1.822 & 2.325 & 0.312 \\
RSCA & -0.457 & 0.003 & 0.451 & 0.398 & $2010-2013$ \\
Côte d'Ivoire & & & & $2005-2009$ & 3.588 \\
YEARS & $1990-1994$ & $1995-1999$ & $2000-2004$ & 1.979 & 0.564 \\
RCA & 2.049 & 2.255 & 1.909 & 0.329 & \\
RSCA & 0.344 & 0.386 & 0.312 & & \\
\hline
\end{tabular}

Source: Author's computation from FAOSTAT (2016)

The result of Ghana's RCA revealed that Ghana recorded an RCA of less than 1 during the 1990 to 1994period, which means that Ghana did not have comparative advantage in the export of palm oil during those years. The level of RCA however increased sharply during the 1995 to 1999 period, this change was reflected with a positive value in the RSCA. The result of Côte d'Ivoire's RCA of palm oil export is also summarized in Table 2 from the result, it could be observed that Côte d'Ivoire's had comparative advantage in the export of palm oil for the whole period of study (1990-2013). This means that Côte d'Ivoire's was highly competitive in the export of palm oil compared to Nigeria and Ghana. The level of competiveness increased during the 1990 to 1999, decreased during the 2000 to 2009 period, and increased sharply during the 2010 to 2013 period. It can be concluded that Côte d'Ivoire's has been highly competitive in the export of palm oil over the period under study, followed by Ghana with Nigeria being the least. Although Nigeria recorded a high production quantity compared to the other countries, it exported less because its production per capita is less compared to the other countries.

\section{Conclusion}

This study analyzed the competitiveness of palm oil export in Nigeria, Ghana and Côte d'Ivoire from 1990 to 2013. The empirical findings suggests that Côte d'Ivoire is highly competitive in the export of palm oil followed by Ghana and lastly Nigeria which is less competitive compared to the aforementioned countries. Although the mean estimates shows that Nigeria's production supersedes that of Ghana and Côte d'Ivoire in terms of quantity. Rehabilitation and establishment of new plantations could ensure Nigeria becomes one of the world's leading exporter of palm oil.

\section{References}

[1] Balassa, B. (1965). Trade Liberalization and Revealed Comparative Advantage. Manchester School of Economics and Social Studies, 33(2), 99-124.

[2] Banterle, A., and Carraresi, L. (2007). Competitive performance analysis and European Union trade: The case of the prepared swine meat sector: Acta Agriculturae Sccandinavica, Section C-Food Economics., 4 (3), 159-172. http://dx.doi.org/10.1080/16507540701597048

[3] Brinkman, G. L. (1987), The Competitive Position of Canadian Agriculture. Canadian Journal of Agricultural Economics/Revue canadienned'agroeconomie, 35: 263-288. doi:10.1111/j.1744-7976.1987.tb02229.x

[4] FAOSTAT (2016).www.faostat.org.Accessed 08/02/2016

[5] Ibrahim K.H. (2015).Trade Complementarities and Similarities between Nigeria and India in the context of Bilateral Trade Relations. IOSR Journal of Economics and Finance, 6(6)28-32

[6] Laursen,K.(2015). Revealed comparative advantage and the alternatives as measures of international specialization. Eurasia Bus Rev 5, 99-115 
Revealed Comparative Advantage and competitiveness: The caseof Palm oil Exportsfrom Nigeria,

[7] Oduro,A.D. and Offei,E.L (2014).Investigating Ghana's Revealed Comparative Advantage in Agro-Processed Products. Modern Economy, 5,384-390

[8] Saboniene,A. (2009).Lithuanian Export Competitiveness: Comparison with other Baltic States.InzinerineEkonomika-Engineering Economics 2,49-57

[9] Valentine, N.andKrasnick,G.(2000). SADC Trade with the Rest of the World: Winning Export Sectors and Revealed Comparative Advantage Ratios. South African Journal of Economics.68, 266-285

[10] Vollrath,T. (1991) A Theoretical Evaluation of Alternative Trade Intensity Measure of Revealed Comparative Advantage. Review of World Economics, 127,265-280

[11] World Bank, (2016) http://wdi.worldbank.org/table/4.2; Accessed 08/02/2016

[12] WTO (World Trade Organization) (2016) WSDBCountryPFView.aspx ?Language $=E \&$ Country $=\mathrm{GH} \% 2 \mathrm{cNG} \% 2 \mathrm{cCI})$. Accessed 08/02/2016

http://stat.wto.org/CountryProfile/

Etuk, E.A. "Revealed Comparative Advantage and competitiveness: The caseof Palm oil Exportsfrom Nigeria, Ghana and Côte d'Ivoire." IOSR Journal of Agriculture and Veterinary Science (IOSR-JAVS) 10.7 (2017): 36-40. 